\title{
Evaluating the Efficiency and Determinants of Efficiency of Rural Health Centers Situated in Punjab, Pakistan
}

\author{
Yuelan Peng1, Muhammad Waqas Akbar' ${ }^{1}$ (), Sofia Anwar², Muhammad Hafeez ${ }^{3}$ \\ ${ }^{1}$ School of Public Finance and Economics Shanxi University of Finance and Economics, Shanxi, China \\ ${ }^{2}$ Department of Economics, Government College University Faisalabad, Faisalabad, Pakistan \\ ${ }^{3}$ School of Economics and Management, Beijing University of Posts and Telecommunications, Beijing, China \\ Email: yl-p@163.com,waqaseco786@gmail.com,sofia_eco@gcuf.edu.pk, hafeez_86@hotmail.com
}

How to cite this paper: Peng, Y.L., Akbar, M.W., Anwar, S. and Hafeez, M. (2019) Evaluating the Efficiency and Determinants of Efficiency of Rural Health Centers Situated in Punjab, Pakistan. Health, 11, 630-645.

https://doi.org/10.4236/health.2019.116053

Received: April 21, 2019

Accepted: June 2, 2019

Published: June 5, 2019

Copyright $\odot 2019$ by author(s) and Scientific Research Publishing Inc. This work is licensed under the Creative Commons Attribution International License (CC BY 4.0).

http://creativecommons.org/licenses/by/4.0/

\begin{abstract}
This study calculates the efficiency of Rural Health Centers (RHCs) and investigates the impact of other variables affecting the efficiency of RHCs. The study considers 29 RHCs, 13 of District Faisalabad, 9 of Toba and 7 of Jhang; a survey was conducted to collect data from each RHC for the year 2016. Data Envelopment Analysis (DEA) model was utilized to get the scores for efficiency. Thereafter, after getting the results from DEA Tobit regression was used in the second stage. Out of the 29 Rural Health Centers, only 11 (38\%) are working efficiently as compare to others. Distance from the tehsil headquarter, Distance from the road with "0" probability, Distance from private hospital with " 0 " probability, Behavior of the staff with " 0.0064 " probability and laboratory equipment's with " 0 " probability, have an impact on the efficiency scores. Distance from other health facilitators, Staff's behavior, list of medicine and equipment's used at RHCs should be improved to increase the efficiency of RHC's.
\end{abstract}

\section{Keywords}

Rural Health Centers, Efficiency, Data Envelopment Analysis

\section{Introduction}

There is a consensus on the importance of health care all over the globe because the healthy population plays a very important role in growing and in the development of an economy [1]. To earn a long lasting return as a prosperity investment in the health sector is very important as a healthy labor force will increase 
the productivity, that is why in recent decades' expenditures on health care are grown in most developed and developing countries [2]. The Governments of most of the developing countries are trying to improve the health care facilities; as it will contribute to improve human welfare, life and their increasing participation in economic growth [3] [4]. To improve human welfare, the Governments should increase the share of the health sector in the annual budget [5].

Pakistan is the 6th most populous country in the world with an estimated population of 200.71 million. To get maximum output from that population health of manpower is very important. Like all other sectors, Pakistan has both private and public sectors in the system of health care. The private health sector has developed over time and has spread across the country. While Pakistan's public health sector was devolved to the provinces. To produce active and productive human capital Governments are trying to improve health sector. Pakistan joined the World Health Organization (WHO) ever since its establishment and launched different programs like; Malaria Control Programs, an Expanded Program of Immunization (EPI), family planning program, etc. as per WHO's guidelines [6].

According to the Economic Survey of Pakistan (2016-2017), the public health activities have insistently increased in terms of infrastructure, workforce. The number of doctors, dentist, nurses and LHVs has increased and the availability of doctor, dentist, nurse and one hospital bed versus population has also been improved. Today, the doctor population ratio is $1: 997$, dentist 1:10,658 and hospital bed 1:1584. While public health infrastructure includes of 1201 hospitals, Basic Health Units 5518, Rural Health Centers 683, 5802 Dispensaries, 731 Maternity \& Child Health Centers, 347 TB centers, and the total availability of beds in these health facilities are 123,394. Even though with an extensive health infrastructure, the delivery of health care facilities suffers from some key issues like the very high population growth, uneven distribution of health professionals, poor workforce, insufficient funding and limited access to quality health care services [7].

Rural Health Centers are making health services available very close to people. The main motive of Rural Health Centers is to provide health care facility like medicine and treatment in the rural areas, awareness of basic health education related to antenatal care for women and basic health facilities for child immunization and to launch programs to control various viral diseases like Tuberculosis, Polio, etc. Different hurdles have been observed in the way of attaining better health in Pakistan like Political instability, poverty and hunger, poor public policies and lack of knowledge about health care [8].

Pakistan has a very vast infrastructure of health facilities and the coverage of health facilities in Pakistan have also been improved over the years. The present network of health services consists of a framework of 1201 Hospitals, 5518 Basic Health Units (BHUs), 683 Rural Health Centers (RHCs), 5802 Dispensaries, 733 mother and child health centers and availability of 1,23,396 beds in hospitals, 
1,95,896 doctors, 18,333 dentists and 99,228 nurses in the country. To reduce disease burden from society different programs are on the track like Programs for Family Planning (PFP), Expanded Programs of Immunization (EPI), Malaria Control Programs (MCP), HIV/AIDS Control Programs, Child Health and Maternal Health Programs, TB Control Programs, Prime Minister's Programs for Prevention and Control of Hepatitis in Pakistan and Cancer Treatment Program. The total expenditures on health during (July-March) 2014-2015 is estimated Rs. 145.97 billion, which is 0.9 percent more than last year [6]. In Pakistan, Punjab is at 1st position in all the provinces with a population of almost 9.82 million and for this huge population the available health institutions are 1201 Medical Dispensaries, 282 Maternity and Child Health Centers (MCH's), 288 Sub-health Centers, 42 Tuberculosis Centers, 2606 Basic Health Units (BHU's), 337 Rural Health Centers (RHC's), and 340 Civil Hospitals are working. Basic health units are always primarily concerned with the development purposes as with Basic health units you can provide health facilities to doorsteps. Every basic health unit consists of one Medical Officer (Doctor), Medical Technician (PMS), Lady Health Workers (LHW), Midwives (MW) and Other Supporting Staff [7].

As we know the healthy labor force plays a very vital role in the Development of any economy and most of the labor force belongs to rural areas of the country. It is very important for Government to provide proper health facilities to the population in order to increase the efficiency of labor force and to cure the health of the non-participant population of the country. To check whether these facilities are properly provided at rural level or not, this study is trying to estimate the efficiency of Rural Health Centers situated in Faisalabad, Jhang and Toba Tek Singh districts.

\section{Data and Methods}

\subsection{Data Source}

Primary data is used in this study. Due to the shortage of time, this study chooses the nearest districts to collect the data for estimating the efficiency of Rural Health Centers. The sample consists of 3 districts and the data about Medical staff, paramedical staff at the RHC's, Medicine stocks, lab equipment's, number of beds, outdoor patient visits, number of family planning visits, number antenatal care visits, no child immunized and no of normal deliveries at RHC is collected for 29 rural health centers, from their concerning Executive District Office of Health (EDO Health) for the year 2014. Therefore, the sampling technique is a convenience sampling technique. In addition, these districts are:

1) Faisalabad;

2) Jhang;

3) Toba Tek Sing.

And the data is collected for 29 rural health centers from their respective Executive District Officer Health's Office (Table 1).

As the study used primary data so a questionnaire was developed to collect the 
data before conducting the survey for this study. I got permission from respective EDO of Faisalabad, Jhang and Toba Tek Singh districts but due to the shortage of time, the study chooses the nearest district "Faisalabad" to collect the data for checking those factors which affect the efficiency of Rural Health Centers. So convenience-sampling technique is used and with the help of their permission all, the staff of the Rural Health Center cooperated well and provides me the complete excess to their equipment's and stores which they use for the stock of medicine. The variables, which are used in the study as input and output variables in to find the efficiency score, are given below with their label and description.

To check the factors affecting the efficiency of Rural Health Centers a Questionnaire was developed and data was collected from the respective Rural Health Centers (Table 2).

Questioner was divided into 6 sections: 1) General Information about Rural Health Center. 2) Infrastructure of the Rural Health Center. 3) Services or the Facilities provided at Rural Health Center. 4) Questions related to Recourses which are used at Rural Health Center were asked. 5) Information about stock of medicine and drugs was collected in this section. 6) This section was about Environmental condition of the Rural Health Centers.

In section 1 questions for general information about location of the RHC, distance from District Health Quarter in kilometers, distance from Tehsil Head Quarters in kilometers, and how many kilometers RHC is away from the road were asked, timing of the Rural Health Center, distance from any private hospital in kilometers and address was asked to know the facts. In second section questions related to infrastructure were asked like total area of the RHC in canals, covered area in canals, no of Rooms, water availability, availability of sui gas facility, telephone generator facility and related to ambulance facility were asked, are these facilities available there " 0 " for no and " 1 " for yes.

In third section questions related to services provided at RHC. Like indoor patient facility, outdoor patient facility, no of wards, no of available beds, is dental room available there, ophthalmology facility available there, is operation theater available, and operation theater is fully equipped or partially equipped, basic laboratory and separate laboratory room is available or not were asked and dummies were created for them like "0" for no and "1" for yes. Do all the staff including senior medical officer, women's medical officer, dental surgeon and medical officer deal with outdoor patients or not, in which patients with malaria, fever due to other causes, vaccine preventable diseases, skin diseases, hypertension, depression, dental caries, injuries, road accidents, fractures, burns, dog bite, and snake bites, indoor and emergency cases also treated there.

Questions about the availability of equipments like X-ray machine, ultrasound machine, and basic laboratory test equipment's are available " 0 " for no "1" for yes and the condition of those equipments was observed in the fourth section. The fifth section was about the stock of medicine and drugs are in surplus or in shortage at RHC "0" for shortage if they have medicine stock for less than 3 
months and surplus if they have medicine stock for more than 6 months, and how the bulk of medicine a Rural Health Center purchased and used. Last but not the least, questions about environment of the RHC were asked and observed like rooms are kept clean or not so "0" for satisfactory and " 1 " for excellent condition was used, as through survey it is noticed that no RHC was with bad condition and where the waste of the RHC was thrown. It is also noticed that how is the condition of the buildings, is it satisfactory and well maintained, do people have easy access to RHC's, are RHC's are near to the main road in the area (Table 3).

Table 1. List of Rural Health Centers.

\begin{tabular}{|c|c|c|c|c|c|c|c|}
\hline Serial No. & RHC's & Tehsil & District & Serial No. & RHC's & Tehsil & District \\
\hline 1 & Chak No. $153 /$ rb & Chak Jhumra & Faisalabad & 16 & Kot shakir & Jhang & Jhang \\
\hline 2 & Chak No. 65/gb & Jaranwala & Faisalabad & 17 & Mochiwala & Jhang & Jhang \\
\hline 3 & Khurrianwala & Jaranwala & Faisalabad & 18 & Mukhiana & Jhang & Jhang \\
\hline 4 & Lundianwala & Jaranwala & Faisalabad & 19 & Rudo sultan & Jhang & Jhang \\
\hline 5 & Satyana & Jaranwala & Faisalabad & 20 & Shah jewena & Jhang & Jhang \\
\hline 6 & Chak No. $229 / \mathrm{rb}$ & Jaranwala & Faisalabad & 21 & Haveli bahadar shah & Shorkot & Jhang \\
\hline 7 & Kanjwani & Tahdianwala & Faisalabad & 22 & Garh. Maharaja & Ahmad Pur Sayal & Jhang \\
\hline 8 & Manmun kanjan & Tahdianwala & Faisalabad & 23 & Chak No. 338/jb nia lahore & Gojra & Toba Tek Singh \\
\hline 9 & Pindi sheikh musa & Tahdianwala & Faisalabad & 24 & Chak No. 740/gb & Kamalia & Toba Tek Singh \\
\hline 10 & Chak No. 134/gb & Samundri & Faisalabad & 25 & Chak No. $316 / g b$ chatiana & Toba Tek Singh & Toba Tek Singh \\
\hline 11 & Mureedwala & Samundri & Faisalabad & 26 & Chak No. 394/jb jaja & Toba Tek Singh & Toba Tek Singh \\
\hline 12 & Chak No. 30/jb & Sadar & Faisalabad & 27 & 133072 RHC Rajana & Toba Tek Singh & Toba Tek Singh \\
\hline 13 & Dijkot & Sadar & Faisalabad & 28 & 133069 RHC Pir mahal & Pir Mehal & Toba Tek Singh \\
\hline 14 & Bagh & Jhang & Jhang & 29 & 133073 RHC Aroti & Pir Mehal & Toba Tek Singh \\
\hline 15 & Haveli shiekh rajoo & Jhang & Jhang & & & & \\
\hline
\end{tabular}

Table 2. Description of variables.

\begin{tabular}{cccl}
\hline Serial No. & Label & Variable & \multicolumn{1}{c}{ Description } \\
\hline $\mathbf{1}$ & MS & Input & Medical Staff Including Senior Medical Officer, Medical Officer, Woman Medical Officer and Dental Surgeon \\
$\mathbf{2}$ & NS & Input & Nursing Staff Including Midwives, Lady Health Visitor and Nurses \\
$\mathbf{3}$ & PMS & Input & $\begin{array}{l}\text { Para Medical Staff Including Dispenser, X-Ray Tech, Dresser Tech, Lab Tech, Theater Assist, Medical Tech, and } \\
\text { EPI Vaccinator }\end{array}$ \\
$\mathbf{4}$ & OS & Input & Other Supporting Staff at RHC Including Naib Qasad, Chowkidar and Sweeper \\
$\mathbf{5}$ & NB & Input & Number of Beds Available at RHC \\
$\mathbf{6}$ & FPV & Output & Number of Family Planning Visits at RHC in a Year \\
$\mathbf{7}$ & ACV & Output & Number Antenatal Care Visits at RHC in a Year \\
$\mathbf{8}$ & OPD & Output & No Out-Door Patient Visits at RHC in a Year \\
9 & CI & Output & No Child Immunized at RHC in a Year \\
10 & ND & Output & No of Normal Deliveries at RHC in a Year \\
\hline & & &
\end{tabular}


Table 3. List of variables generated from questioner and their description.

\begin{tabular}{|c|c|c|}
\hline Sections & Variables & Description of Variable \\
\hline \multirow{4}{*}{1} & 1) Dist_DHQ & Distance of Rural Health Center from District Health Quarter in Kilometers (Km) \\
\hline & 2) Dist_THQ & Distance of Rural Health Center from Tehsil Health Quarter in Kilometers (Km) \\
\hline & 3) Dist_Road & Distance of Rural Health Center from Main Road in Kilometers (Km) \\
\hline & 4) Dist_Prvt & Distance of Rural Health Center from Private Hospitals in Kilometers (Km) \\
\hline 2 & 5) Cleanliness & $\begin{array}{l}\text { Dummy Was Generated from Hospitals Wastage, Toilet Conditions, Air Pollution, and Environment } \\
\text { of Rooms. } 1 \text { = Excellent (All Are in a Good Condition), } 0 \text { = Satisfactory (All Are in a Normal Condition) }\end{array}$ \\
\hline 3 & 6) Beh_Staff & Dummy is Created for Behavior of Staff, $0=$ Rude Behavior and $1=$ Friendly Behavior \\
\hline 4 & 7) Avail_Staff & $\begin{array}{l}\text { Availability of Medical Staff and Paramedical Staff, } 1=\text { Both Types of Staff Available, } 0=\text { Having Only } \\
\text { One Staff }\end{array}$ \\
\hline 5 & 8) Lab_Equi & $\begin{array}{l}\text { Laboratory Equipment's Like X-Ray Machine, Ultrasound Machine, Basic Laboratory Test Equipment's } \\
1=\text { Fully Equipped, } 0=\text { Partially Equipped }\end{array}$ \\
\hline 6 & 9) Opera_Equi & Operation Equipment's, 1 = Fully Equipped Surgical Instruments, $0=$ Partially Equipped \\
\hline 7 & 10) Med_Stoc & $\begin{array}{l}\text { Medicine Stock, } 1=\text { Surplus (Medicines Available for More than } 6 \text { Months), } 0=\text { Shortage } \\
\text { (Medicines Available for Less than } 6 \text { Months) }\end{array}$ \\
\hline
\end{tabular}

\subsection{Methods}

The concept of measuring efficiency has been analyzed since Adam Smith's era and before. There are different methods available to measure the efficiency. Efficiency can be measured by Parametric and Non-parametric techniques. Parametric approach further divided into Deterministic frontier analysis and stochastic frontier analysis, these techniques require functional form and the disturbance term.

Methodology is a very important component of the study. In addition, there are many techniques available, which can be used to estimate the efficiency of any sector like education, Health, Banking sector, etc. From previous studies, it has been noticed that estimation of efficiency is very important for better use and the best allocation of resources.

Data Envelopment Analysis was presented initially by Charnes et al. (1978) as the concept they followed had been taken from the work of Farrell 1957. DEA is a non-parametric technique and it gives productive efficiency scores of Decision Making Units. Non-parametric technique does not have any specific shape of the frontier curve, and it does not estimate any relationship between inputs and outputs. However, it can be used to compare the efficiency scores of different units. There are two types of DEA, one is based on the Constant Return to Scale (CRS) and the other one is based on Variable Return to Scale (VRS). Data Envelopment Analysis can be run by both the methods, either cost minimizing method or output maximizing method. In the cost minimizing method, output is fixed and on that output, we try to minimize our cost. Whereas in output maximization method cost kept fixed and tries to maximize the output [9] [10] [11].

\section{Economic Efficiency $=$ Technical Efficiency $\times$ Allocative Efficiency}

Efficiency of Rural Health Centers have been analyzed by using the Data En- 
velopment Analysis technique in the first stage after getting the efficiency scores, Tobit regression is used to find different determinants of the efficiency in the second stage. The concept of measuring efficiency has been analyzed since Adam Smith's era and before. There are different methods available to measure the efficiency. Efficiency can be measured by Parametric and Non-parametric techniques. Parametric approach further divided into Deterministic frontier analysis and stochastic frontier analysis, these techniques require functional form and the disturbance term [12].

Term Data Envelopment Analysis (DEA) was first introduced by Charnes et al. (1978) But the concept they followed has been taken from the work of Farrell 1957. Data Envelopment Analysis is a non-parametric technique that gives productive efficiency scores of DMU's [13] [14] [15].

The variables used in the study as input and output in the efficiency analysis through Data Envelopment Analysis are Para Medical staff, nursing staff, Medical staff, Other Supporting Staff and number of beds are the input variables and Number of Family Planning, Number Antenatal Care, Number of Out-door Patient, Number of Child immunized and Number of Normal deliveries used as output variables.

\section{Estimation of Factors Affecting Efficiency}

To estimate the factors, which affect the efficiency of Rural Health Centers, this study applies the Tobit regression and the description about variables is given in (Table 4).

Models for Tobit Regression

EFFICIENCY $=\beta_{0}+\beta_{1}$ Dist_THQ $+\beta_{2}$ Dist_Road $+\beta_{3}$ Dist_Prvt $+\beta_{4}$ Cleanliness $+\beta_{5}$ Beh_Staff $+\beta_{6}$ Avail_Staff $+\beta_{7}$ Lab_Equi $+\beta_{8}$ Opera_Equi $+\beta_{9}$ Med_Stock $+\beta_{10}$ Dist_DHQ

\section{Results and Discussions}

The descriptive statistics of output and input variables which are the products or output of Rural Health Centers by using a set of outputs and these outputs are used in calculating efficiency by using Data Envelopment Analysis. As the (Table 5) shows that minimum family planning visits to a Rural Health Center were 102 and maximum were 9184 in 2014. Minimum antenatal care visits were 148 and maximum were 2531. Maximum outdoor patients facilitated from a Rural Health Center in 2014 were 77,494 and minimum visits were 54. 1743 chilled were immunized from Rural Health Center and the minimum amounts of immunized children were 100. The maximum amounts of normal deliveries in a Rural Health Center were 938 in the year 2014 and the minimum amount was 14 . The descriptive statistics of input variables which are used in Rural Health Centers to produce outputs in the shape of people facilitated from there. The minimum no of Medical Staff at any of the Rural Health Center is 3 and the total no of Medical Staff allowed to each Rural Health Center is 4 which includes 1 Senior Medical Officer, 1 Women Medical Officer, 1 Medical Officer and 1 
Dental Surgeon. These above-mentioned input variables used in Data Envelopment Analysis to calculate the technical efficiency of Rural Health Centers. The minimum and maximum amount of each input variable is shown in the (Table 5).

The frequencies of different variables are shown in (Table 6). In district Faisalabad there are 7 Rural Health Centers are fully equipped with laboratory equipment's that there is all type of machines available for laboratory usage. And out of total 13, Rural Health Centers 6 is those which are not fully equipped that there is lack of machinery. Partially equipped means that there is shortage of machinery which are necessary for laboratory tests. Like blood CP, blood cross matching, blood sugar, pregnancy test, hepatitis b, hepatitis c, TB micro, Stool RE, HIV and Urine RE. Out of total 13 Rural Health Centers of Faisalabad, only 5 Rural Health Centers have complete equipment's for minor surgeries and 8 RHC's are those which do not have complete operational equipment's available there.

Table 4. Variable description.

\begin{tabular}{|c|c|}
\hline Short Form & Description of Variable \\
\hline Dist_DHQ & Distance of Rural Health Center from District Health Quarter in Kilometers (Km). \\
\hline Dist_THQ & Distance of Rural Health Center from Tehsil Health Quarter in Kilometers (Km). \\
\hline Dist_Road & Distance of Rural Health Center from Main Road in Kilometers (Km). \\
\hline Dist_Prvt & Distance of Rural Health Center from Private Hospitals in Kilometers (Km). \\
\hline Cleanliness & $\begin{array}{l}\text { Dummy Was Generated from Hospitals Wastage, Toilet Conditions, Air Pollution, and Environment of Rooms, } \\
1 \text { = Excellent (All Are in a Good Condition), } 0=\text { Satisfactory (All Are in a Normal Condition). }\end{array}$ \\
\hline Beh_Staff & $\begin{array}{l}\text { Dummy is Created for Behavior of Staff, } 0=\text { Rude Behavior, } \\
1=\text { Friendly Behavior. }\end{array}$ \\
\hline Avail_Staff & $\begin{array}{l}\text { Availability of Medical staff And Paramedical Staff, } 1=\text { Both Types of Staff Available, } \\
0=\text { Having Only One Staff. }\end{array}$ \\
\hline Lab_Equi & $\begin{array}{l}\text { Laboratory Equipment's Like X-Ray Machine, Ultrasound Machine, Basic Laboratory Test Equipments, } \\
1 \text { = Fully Equipped, } 0=\text { Partially Equipped. }\end{array}$ \\
\hline Opera_Equi & $\begin{array}{l}\text { Operation Equipment's, } 1 \text { = Fully Equipped Surgical Instruments, } \\
0=\text { Partially Equipped. }\end{array}$ \\
\hline Med_Stock & $\begin{array}{l}\text { Medicine Stock, } 1=\text { Surplus (Medicines Available for More than } 6 \text { Months), } 0=\text { Shortage (Medicines Available for } \\
\text { Less than } 6 \text { Months). }\end{array}$ \\
\hline
\end{tabular}

Table 5. Result of descriptive statistics of output variables and input variables.

\begin{tabular}{cccccccc}
\hline \multicolumn{3}{c}{ Output Variables } & & \multicolumn{3}{c}{ Intput Variables } \\
\hline Variables & N & Minimum & Maximum & Variables & N & Minimum & Maximum \\
\hline Family Planning Visits & 29 & 102 & 9184 & Medical Staff & 29 & 3 & 4 \\
Antenatal Care Visits & 29 & 148 & 2531 & Nursing Staff & 29 & 11 & 12 \\
Outdoor Patient Visits & 29 & 54 & 77494 & Para Medical Staff & 29 & 8 & 11 \\
Chilled Immunized & 29 & 100 & 1743 & Other Supporting Staff & 29 & 9 & 11 \\
Normal Deliveries & 29 & 14 & 938 & No. of Beds & 29 & 6 & 20 \\
\hline
\end{tabular}


Table 6. Frequencies of laboratory equipments, operational equipments, cleanliness and maintenance of the rooms, distance from DHQ, distance from THQ and distance from private hospitals.

\begin{tabular}{|c|c|c|c|c|c|c|c|c|}
\hline \multicolumn{3}{|c|}{ Laboratory Equipments } & \multicolumn{3}{|c|}{ Operational Equipments } & \multicolumn{3}{|c|}{ Cleanliness and Maintenance of the Rooms } \\
\hline & Frequency & Valid Percent & & Frequency & Valid Percent & & Frequency & Valid Percent \\
\hline $\begin{array}{l}\text { Partially } \\
\text { Equipped }\end{array}$ & 6 & 46.2 & $\begin{array}{l}\text { Partially } \\
\text { Equipped }\end{array}$ & 8 & 61.5 & Satisfactory & 3 & 23.1 \\
\hline $\begin{array}{l}\text { Complete } \\
\text { Equipped }\end{array}$ & 7 & 53.8 & Fully Equipped & 5 & 38.5 & Excellent & 10 & 76.9 \\
\hline Total & 13 & 100 & Total & 13 & 100 & Total & 13 & 100 \\
\hline \multicolumn{3}{|c|}{ Distance from DHQ } & \multicolumn{3}{|c|}{ Distance from THQ } & \multicolumn{3}{|c|}{ Distance from Private hospital } \\
\hline & Frequency & Valid Percent & & Frequency & Valid Percent & & Frequency & Valid Percent \\
\hline $0-25 \mathrm{Km}$ & 6 & 46.2 & $0-15 \mathrm{Km}$ & 2 & 15.4 & $0-4 \mathrm{Km}$ & 7 & 53.8 \\
\hline $25-50 \mathrm{Km}$ & 2 & 15.4 & $15-20 \mathrm{Km}$ & 2 & 15.4 & $4-6 \mathrm{Km}$ & 3 & 23.1 \\
\hline $50-75 \mathrm{Km}$ & 4 & 30.7 & $20-25 \mathrm{Km}$ & 7 & 53.8 & $6-8 \mathrm{Km}$ & 0 & 0 \\
\hline $75-100 \mathrm{Km}$ & 1 & 7.7 & $25-35 \mathrm{Km}$ & 2 & 15.4 & $8-10 \mathrm{Km}$ & 3 & 23.1 \\
\hline Total & 13 & 100 & Total & 13 & 100 & Total & 13 & 100 \\
\hline
\end{tabular}

Table 6 also showed the frequencies that how much rooms are kept clean and maintained the condition of the rooms suitable for patients. Are sweepers done their work properly. A dummy variable is used to observe the condition of rooms and surroundings so " 1 " is given if rooms are excellently clean and maintained and "0" is given if rooms are satisfactorily clean and maintained. The frequencies show that out of 13,10 RHC's are excellently clean and 3 have satisfactory condition.

There are 6 Rural Health Centers (RHC) in Faisalabad district which are 0 to 6 Km away from District Head Quarter (DHQ), 2 RHCs are 25 to $50 \mathrm{Km}$ away from the respective DHQ, from 50 to $75 \mathrm{Km}$ there are 4 RHCs and 1 is in between 75 to $100 \mathrm{Km}$. Then we find the distance of RHCs from the respective Tehsil Head Quarter (THQ), there are 2 RHCs which are 0 to $15 \mathrm{Km}$ away from THQ, 2 are 15 to $20 \mathrm{Km}$ away, 7 RHCs are 20 to $25 \mathrm{Km}$ away and 2 are 25 to 35 $\mathrm{Km}$ away from the respective THQ. Distance from Private hospital is also measured in this study so the study finds out that 7 RHCs are 0 to $4 \mathrm{Km}$ away from a private hospital, 3 are 4 to $6 \mathrm{Km}$ away and 3 are 8 to $10 \mathrm{Km}$ away from a private hospital.

The results of outputs and with the help of this information, top Rural Health Centers and lower performance Health Centers can be checked. Mukhiana, Rudo Sultan, Kot Shakir, Bagh, Garh Maharaja, Mochiwala, Shah Jewena, Haveli Bahadar Shah, Haveli Shiekh Rajoo, Satyana, Pindi Sheikh Musa, Chak No. 229/RB, Chak No. 153/RB, Chak No. 30/JB are those Rural Health Centers which have maximum family planning visits from 1000 to 9000 in 2014 and the remaining Chak No. 740/GB, Mureedwala, Lundianwala, Dijkot, Pir Mahal, Chak 
No. 65/GB, Rajana, Kanjwani, Chak No. 338/JB Nia Lahore, Chak No. 394/JB JAJA, Manmun Kanjan, Khurrianwala, Chak No. 134 GB, Aroti and Chak No. 316/GB Chatiana are those Rural Health Centers which have minimum family planning visits from 100 to 600 in 2014 (Table 7).

Table 7. Detail of output variables.

\begin{tabular}{|c|c|c|c|c|c|c|c|c|}
\hline \multicolumn{9}{|c|}{ Output Variables } \\
\hline Serial No. & RHC's & Tehsil & Districts & FPV & ANC & $\mathrm{CI}$ & ODP & ND \\
\hline 1 & Chak No. 153/RB & Chak Jhumra & Faisalabad & 1407 & 1120 & 644 & 43,920 & 351 \\
\hline 2 & Chak No. 65/GB & Jaranwala & Faisalabad & 477 & 1635 & 548 & 57,601 & 392 \\
\hline 3 & Khurrianwala & Jaranwala & Faisalabad & 154 & 910 & 985 & 76,759 & 288 \\
\hline 4 & Lundianwala & Jaranwala & Faisalabad & 519 & 1172 & 201 & 31,869 & 248 \\
\hline 5 & Satyana & Jaranwala & Faisalabad & 2054 & 2531 & 794 & 75,458 & 444 \\
\hline 6 & Chak No. 229/RB & Jaranwala & Faisalabad & 1617 & 913 & 924 & 56,214 & 185 \\
\hline 7 & Kanjwani & Tahdianwala & Faisalabad & 405 & 1015 & 751 & 53,138 & 247 \\
\hline 8 & Manmun kanjan & Tahdianwala & Faisalabad & 203 & 2048 & 885 & 54,512 & 201 \\
\hline 9 & Pindi Sheikh Musa & Tahdianwala & Faisalabad & 1766 & 636 & 732 & 23,979 & 196 \\
\hline 10 & Chak No. 134 GB & Samundri & Faisalabad & 151 & 148 & 100 & 14,292 & 104 \\
\hline 11 & Mureedwala & Samundri & Faisalabad & 548 & 835 & 606 & 31,926 & 202 \\
\hline 12 & Chak No. 30/JB & Sadar & Faisalabad & 1229 & 744 & 526 & 39,584 & 142 \\
\hline 13 & Dijkot & Sadar & Faisalabad & 487 & 1322 & 943 & 77,494 & 222 \\
\hline 14 & Bagh & Jhang & Jhang & 8066 & 1896 & 821 & 89 & 647 \\
\hline 15 & Haveli Shiekh Rajoo & Jhang & Jhang & 2837 & 981 & 1743 & 112 & 566 \\
\hline 16 & Kot Shakir & Jhang & Jhang & 8461 & 473 & 960 & 141 & 585 \\
\hline 17 & Mochiwala & Jhang & Jhang & 6946 & 689 & 888 & 136 & 938 \\
\hline 18 & Mukhiana & Jhang & Jhang & 9184 & 995 & 1335 & 157 & 107 \\
\hline 19 & Rudo Sultan & Jhang & Jhang & 8550 & 950 & 1242 & 101 & 99 \\
\hline 20 & Shah Jewena & Jhang & Jhang & 4710 & 728 & 742 & 54 & 179 \\
\hline 21 & Haveli Bahadar Shah & Shorkot & Jhang & 4348 & 1338 & 790 & 87 & 372 \\
\hline 22 & Garh. Maharaja & Ahmad Pur Sayal & Jhang & 6974 & 957 & 1193 & 109 & 178 \\
\hline 23 & Chak No. 338/JB Nia Lahore & Gojra & Toba Tek Singh & 315 & 1219 & 798 & 28,113 & 194 \\
\hline 24 & Chak No. 740/GB & Kamalia & Toba Tek Singh & 574 & 328 & 1430 & 17,827 & 106 \\
\hline 25 & Chak No. 316/GB Chatiana & Toba Tek Singh & Toba Tek Singh & 102 & 902 & 743 & 22,067 & 161 \\
\hline 26 & Chak No. 394/JB Jaja & Toba Tek Singh & Toba Tek Singh & 272 & 660 & 647 & 17,197 & 150 \\
\hline 27 & Rajana & Toba Tek Singh & Toba Tek Singh & 473 & 1168 & 1450 & 27,489 & 148 \\
\hline 28 & Pir Mahal & Pir Mehal & Toba Tek Singh & 484 & 1284 & 1611 & 22,321 & 97 \\
\hline 29 & Aroti & Pir Mehal & Toba Tek Singh & 107 & 276 & 450 & 10,608 & 14 \\
\hline
\end{tabular}


Rural Health Centers located in Satyana, Mammun Kanjan, Bagh, Chak No. 65/GB, Haveli Bahadar Shah, Dijkot, Pir Mahal, Chak No. 338/JB Nia Lahore, Lundianwala, Rajana, Chak No. 153/RB, Kanjwani are in top 15 with maximum Antenatal Care Visits from 1000 to 2500 and the remaining health centers situated in Mukhiana, Haveli Shiekh Rajoo, Garh Maharaja, Rudo Sultan, Chak No. 229/RB, Khurrianwala, Chak No. 316/GB, Chatiana, Mureedwala, Chak No. 30/JB, Shah Jewena, Mochiwala, Chak No. 394/JB Jaja, Pindi Sheikh Musa, Kot Shakir, Chak No. 740/GB, Aroti, Chak No. 134 GB are with minimum Antenatal Care Visits from 150 to 995.

The above table shows the results of outputs and with the help of this information top Rural Health Centers and lower performance Health Centers can be checked. Mukhiana, Rudo Sultan, Kot Shakir, Bagh, Garh Maharaja, Mochiwala, Shah Jewena, Haveli Bahadar Shah, Haveli Shiekh Rajoo, Satyana, Pindi Sheikh Musa, Chak No. 229/RB, Chak No. 153/RB, Chak No. 30/JB are those Rural Health Centers which have maximum family planning visits from 1000 to 9000 in 2014 and the remaining Chak No. 740/GB, Mureedwala, Lundianwala, Dijkot, Pir Mahal, Chak No. 65/GB, Rajana, Kanjwani, Chak No. 338/JB Nia Lahore, Chak No. 394/JB JAJA, Manmun Kanjan, Khurrianwala, Chak No. 134 GB, Aroti And Chak No. 316/GB Chatiana are those Rural Health Centers which have minimum family planning visits from 100 to 600 in 2014.

Rural Health Centers located in Satyana, Mammun Kanjan, Bagh, Chak No. 65/GB, Haveli Bahadar Shah, Dijkot, Pir Mahal, Chak No. 338/JB Nia Lahore, Lundianwala, Rajana, Chak No. 153/RB, Kanjwani are in top 15 with maximum Antenatal Care Visits from 1000 to 2500 and the ramaining health centers situated in Mukhiana, Haveli Shiekh Rajoo, Garh Maharaja, Rudo Sultan, Chak No. 229/RB, Khurrianwala, Chak No. 316/GB Chatiana, Mureedwala, Chak No. 30/JB, Shah Jewena, Mochiwala, Chak No. 394/JB Jaja, Pindi Sheikh Musa, Kot Shakir, Chak No. 740/GB, Aroti, Chak No. 134 GB are with minimum Antenatal Care Visits from 150 to 995. In the field of outdoor patient treatment Dijkot, Khurianwala, Satyana, 65 Chak awaghat, 229 GB are in top 5 Rural Health Centers and Garh Maharaja, Rudo Sultan, Bagh, Haveli Bahadur Shah and Shah Jewwana are at the lowest place out of 29 Rural Health Centers.

In Child Immunization Haveli sheikh rajoo, Pir mehal, Rajan, Chak 740 GB, Mukhiana are in top 5 RHC's and 65 Chak, 30/JB, Aroti, Lundianwala and 134 GB are at below 25 out of 29 RHC's. Mochiwala, Kot Shakir, Haveli Sheikh Rajoo, Kanjwani, Murid wala, Chak 229 makuana, 30 JB, 740 GB, Rudo Sultan, Pir mehal and Khurianwala have less medical staff as compare to other Rural Health Centers.

Table 8 gives complete information about the Rural Health Centers that how much inputs are used in the form of Medical Staff, Paramedical Staff, Nursing Staff, Other Staff and number of Beds.

\section{Results of DEA Model}

Results of DEA are reported in the Table below. Efficiency scores have been cal- 
culated by taking Medical Staff including (Senior Medical Officer, Woman Medical Officer, Medical Officer and Dental Surgeon), Nursing Staff, Paramedical Staff and Other Supporting Staff as input variables and Family Planning Visits, Antenatal Care Visits, Outdoor Patient Visits, Child Immunization and Normal Deliveries as output variables.

Results of technical efficiency are described in (Table 8), at the first results of technical efficiency of Faisalabad are described, then results of Jhang and after that results of Toba Tek Singh district are described.

The results of the DEA under constant return to scale, variable return to scale of Rural Health Centers of districts Faisalabad, Jhang and Toba Tek Singh calculations tell that in District Faisalabad there are three Rural Health Centers out of 29 are those working on the production possibility frontiers line; and these are located in Tehsil Khurianwala, Satyana and Dijkot their efficiency score is $100 \%$. There is only one Rural Health Center, which has an efficiency score of $90 \%$, which is close the to $100 \%$ efficiency score.

Five are working well above the average efficiency score, with efficiency score to $70 \%$ to $80 \%$ and they are in Tehsil Jhumra, Jaranwala and Tandlianwala. $23 \%$ of the Rural Health Centers are those which are working inefficiently as their efficiency score is quite below the average efficiency score but above $50 \%$ as they have an efficiency score between $50 \%$ and $60 \%$ there is $40 \%$ capacity available to increase their productivity. Rural Health Center situated at Chak No. 134 GB showed $20 \%$ efficiency score which is very disappointed as that is working totally inefficiently and there is $80 \%$ capacity available to increase its productivity to production possibility frontier. According to variable return to scale out of 20 Rural Health Centers 9 are working quite efficiently as their scores are 100\% and 4 Rural Health Centers are quite close to $100 \%$ with an efficiency score of above $90 \%$.

Out of 9 Rural Health Centers in district Jhang, 6 are working well efficiently as their efficiency scores are $100 \%$ and all these are located in Tehsil Jhang. Remaining three Rural Health Centers have an efficiency score of 0.928, 0.864 and 0.718 which are quite above the average efficiency score and they are situated at Havlei Bahadar Shah, Garh Maharaja and Shah Jewana and it is also noticed that there is a capacity available to increase their efficiency and same is the case with Scale efficiency. According to variable return to scale 8 Rural Health Centers have an efficiency score equals to 1 out of 9 Rural Health Centers. Only one Rural Health Center is below $100 \%$, but quite close to $100 \%$ with an efficiency score of 0.935 .

There are seven Rural Health Centers a located in district Toba Tek Singh out of which only 2 are working efficiently on the production possibility frontier as shown in the above table. One is working at 0.987 which is almost equal to 1 . So Rural Health Centers situated in Kamalia, Toba Tek Singh, and Pir Mehal is efficient centers in District Toba Tek Singh. Rural Health Centers of tehsil Gojra and one of the Tehsil Toba Health Centers is at below average as their efficiency 
score is 0.681 and 0.567 ; there is a capacity of increasing their efficiency by $32 \%$ and $43 \%$ with increasing return to scale. Rural Health Center of Aroti and 394/GB Jaja are the poor in efficiency as their efficiency score is 0.484 and 0.308 there is a lot of space to increase their efficiency by increasing their output because there is no need to increase their inputs as they have enough inputs at theirs. According to variable return to scale 3 Rural Health Centers are working on the production possibility frontier and remaining 4 are above $90 \%$ which is close to $100 \%$.

To find out the determinants of the efficiency of Rural Health Centers, the Data Envelopment Analysis technique has been used. Thereafter efficiency scores obtained and regressed by different variables related to Rural Health Centers. Descriptive analysis is presented earlier than the results.

Factors affecting and determinants of Efficiency of Rural Health Centers are examined by using Tobit regression. When the dependent variable is in censored form, we use Tobit regression and as we know efficiency scores showed above are in censored form from 0 to 1 so Tobit regression is used and the results are discussed in (Table 9).

Table 8. Efficiency scores of Rural Health Centers in District Faisalabad, JHANG and Toba Tek Singh.

\begin{tabular}{|c|c|c|c|c|c|c|c|c|c|c|c|}
\hline \multicolumn{4}{|c|}{ District Faisalabad } & \multicolumn{4}{|c|}{ District Jhang } & \multicolumn{4}{|c|}{ District Toba Tek Singh } \\
\hline S \# & RHC & $\begin{array}{l}\text { Tech Eff } \\
\text { at CRS }\end{array}$ & $\begin{array}{l}\text { Tech Eff } \\
\text { at VRS }\end{array}$ & S \# & RHC & $\begin{array}{l}\text { Tech Eff } \\
\text { at CRS }\end{array}$ & $\begin{array}{l}\text { Tech Eff } \\
\text { At VRS }\end{array}$ & $S \#$ & RHC & $\begin{array}{l}\text { Tech Eff } \\
\text { at CRS }\end{array}$ & $\begin{array}{l}\text { Tech Eff } \\
\text { at VRS }\end{array}$ \\
\hline 1 & $\begin{array}{c}\text { Chak No. } 153 \text { RB } \\
\text { Jhumra }\end{array}$ & $88 \%$ & $100 \%$ & 1 & Bagh & $100 \%$ & $100 \%$ & 1 & $\begin{array}{c}\text { Chak No. } 338 \text { JB } \\
\text { Nia Lahore }\end{array}$ & $68.10 \%$ & $95 \%$ \\
\hline 2 & $\begin{array}{c}\text { Chak No. } 65 \text { GB } \\
\text { Awagat }\end{array}$ & $82.60 \%$ & $95.70 \%$ & 2 & Haveli Shiekh Rajoo & $100 \%$ & $100 \%$ & 2 & Chak No. 740 GB & $98.70 \%$ & $100 \%$ \\
\hline 3 & Khurrianwala & $100 \%$ & $100 \%$ & 3 & Kot Shakir & $100 \%$ & $100 \%$ & 3 & $\begin{array}{c}\text { Chak No. } 316 \text { GB } \\
\text { Chatiana }\end{array}$ & $56.70 \%$ & $93.50 \%$ \\
\hline 4 & Lundianwala & $77 \%$ & $100 \%$ & 4 & Mochiwala & $100 \%$ & $100 \%$ & 4 & $\begin{array}{c}\text { Chak } \\
\text { No. } 394 \text { JB Jaja }\end{array}$ & $48.40 \%$ & $92.60 \%$ \\
\hline 5 & Satyana & $100 \%$ & $100 \%$ & 5 & Mukhiana & $100 \%$ & $100 \%$ & 5 & Rajana & $100 \%$ & $100 \%$ \\
\hline 6 & $\begin{array}{c}\text { Chak } \\
\text { No. } 229 \text { RB }\end{array}$ & $88.60 \%$ & $95.50 \%$ & 6 & Rudo Sultan & $100 \%$ & $100 \%$ & 6 & Pir Mahal & $100 \%$ & $100 \%$ \\
\hline 7 & Kanjwani & $74.50 \%$ & $94.70 \%$ & 7 & Shah Jewena & $71.80 \%$ & $100 \%$ & 7 & Aroti & $30.80 \%$ & $94.40 \%$ \\
\hline 8 & $\begin{array}{l}\text { Manmun } \\
\text { Kanjan }\end{array}$ & $90.80 \%$ & $100 \%$ & 8 & Haveli Bahadar Shah & $92.80 \%$ & $100 \%$ & & & & \\
\hline 9 & $\begin{array}{c}\text { Pindi } \\
\text { Sheikh Musa }\end{array}$ & $60.00 \%$ & $100 \%$ & 9 & Garh. Maharaja & $86.40 \%$ & $93.50 \%$ & & & & \\
\hline 10 & $\begin{array}{c}\text { Chak } \\
\text { No. } 134 \text { GB }\end{array}$ & $21.30 \%$ & $100 \%$ & & & & & & & & \\
\hline 11 & Mureedwala & $58.30 \%$ & $100 \%$ & & & & & & & & \\
\hline 12 & $\begin{array}{c}\text { Chak } \\
\text { No. 30/JB }\end{array}$ & $59.20 \%$ & $93.80 \%$ & & & & & & & & \\
\hline 13 & Dijkot & $100 \%$ & $100 \%$ & & & & & & & & \\
\hline
\end{tabular}


Table 9. Result of tobit regression.

\begin{tabular}{|c|c|c|c|c|}
\hline \multicolumn{5}{|c|}{ Dependent Variable: Efficiency CRS } \\
\hline \multicolumn{5}{|c|}{ Method: ML-Censored Normal (TOBIT) } \\
\hline Sample: 1 - 13 & \multicolumn{4}{|c|}{ Included Observations: 13} \\
\hline \multicolumn{5}{|c|}{ Left Censoring (Value) at Zero } \\
\hline \multicolumn{5}{|c|}{ Convergence Achieved after 8 Iterations } \\
\hline \multicolumn{5}{|c|}{ Coefficient Covariance Computed Using Observed Hessian } \\
\hline Variable & Coefficient & Std. Error & z-Statistic & Prob. \\
\hline Distance from Tehsil Head Quarter & 0.015 & 0.003 & 4.236 & 0 \\
\hline Distance from Road & -0.194 & 0.020 & -9.582 & 0 \\
\hline Distance from Private hospital & 0.046 & 0.004 & 11.575 & 0 \\
\hline Cleanliness & 0.233 & 0.0293 & 7.936 & 0 \\
\hline Behavior of the Staff & 0.086 & 0.031 & 2.727 & 0.006 \\
\hline Availability of the Staff & 0.037 & 0.0206 & 1.777 & 0.075 \\
\hline Laboratory Equipments & 0.150 & 0.024 & 6.232 & 0 \\
\hline Operation Equipments & 0.005 & 0.023 & 0.222 & 0.8241 \\
\hline Medicine Stock & -0.0325 & 0.025 & -1.289 & 0.197 \\
\hline Distance from District Head Quarter & -0.001 & 0.001 & -1.181 & 0.237 \\
\hline $\mathrm{C}$ & 0.3655 & 0.0603 & 6.063 & 0 \\
\hline
\end{tabular}

Variable Distance from Tehsil Head Quarter measures how far Rural Health Centers is from Tehsil Head Quarter, the variable is positively significant at $1 \%$ level, the coefficient tells that as the distance between THQ and RHC increases the efficiency of RHC will increase by 0.015 and the p-value is " 0 " which means it is statistically significant. As the distance between THQ and RHC increases people will go to RHC's rather going to THQ's.

Coefficient of Distance from Roads negatively significant at $1 \%$ level o as shown in Table 9. This distance is between the main road and Rural Health Centers. In addition, the coefficient indicates that Rural Health Centers, which are located on the main road the efficiency of those Rural Health Centers, are higher than the RHC's far away from the main road. There is a negative relation between Distance from Road and Efficiency as the distance increases the efficiency decreases by 0.19 units and the p-value is "0" which is less than alpha which means it is statistically significant.

There are some private hospitals near the RHC's and the variable Distance from the private hospital show positive and significant effect on efficiency at $1 \%$ level of significance. As the distance between private hospitals and Rural Health Centers increases the efficiency of the RHC's will also increase by 0.046 units because people will go to Rural Health Centers than going to private hospitals its p-value is also " 0 " it means it is statistically significant.

Maintenance and cleanliness of the rooms also affect the efficiency of Rural 
Health Centers. Cleanliness is positively significant at $1 \%$ level of significance and the coefficient of Cleanliness shows that efficiency of Rural Health Centers with excellent condition will 0.233 units higher than the RHC's with satisfactory condition.

The behavior of the staff also has a positive impact on efficiency. Coefficient of the behavior of the staff is positively significant at $1 \%$ level and shows that efficiency is 0.086 units higher of those Rural Health Centers where staff has friendly behavior with their patients than the Rural Health Centers where staff has rude behavior with their patients and the p-value is " 0 " which means it is statistically significant.

Availability of the Staff is a variable which tells that the presence of the staff affects the efficiency of Rural Health Centers or not. The above table shows that it is positively significant at $10 \%$ level and the coefficient shows that the efficiency of the Rural Health Centers is 0.037 units higher where staff is full time available.

Laboratory equipment has a positive and significant impact on the efficiency of RHC's at $1 \%$ level of significance. The result indicates that efficiency of those Rural Health Centers is 0.15 units higher which are fully equipped with laboratory equipment than RHC's which are partially equipped. Operation equipment have a positive but insignificant impact on efficiency and the coefficient shows that there is no difference in the efficiency of those Rural Health Centers which have full operation equipment and those which are partially equipped.

Coefficient of Medicine stock shows that medicine stock doesn't have any impact on efficiency as Rural Health Centers where medicine stack is in surplus and where their medicine stack is in shortage have the same efficiency scores and the p-value is " 0 " which means it is statistically significant. Coefficient of Distance between Rural Health Centers and District Head Quarters shows that there is no effect on the efficiency of this variable as it has an insignificant impact on efficiency score.

\section{Conflicts of Interest}

The authors declare no conflicts of interest regarding the publication of this paper.

\section{References}

[1] Asandului, L., Roman, M. and Fatulescu, P. (2014) The Efficiency of Healthcare Systems in Europe: A Data Envelopment Analysis Approach. Procedia Economics and Finance, 10, 261-268. https://doi.org/10.1016/S2212-5671(14)00301-3

[2] Tendon, A.C., Murray, J. and Evans, L.D. (2001) Measuring Overall Health System Performance for 191 Countries. GPE Discussion Paper Series, No.30.

[3] Punjab Rural Support Program (2014) Government of Punjab, Lahore, Punjab, Pakistan, PRSP 2013-2014.

[4] Razzaq, S., Chaudhary, A.A. and Khan, A.R. (2013) Efficiency Analysis of Basic Health Units: A Comparison of Developed and Deprived Regions in Azad Jammu 
and Kashmir. Iranian Journal of Public Health, 42, 1223-1231.

[5] Adam, T., et al. (2006) Determinants of Variation in the Cost of Inpatient Stays versus Outpatient Visits in Hospitals: A Multi-Country Analysis. Social Science \& Medicine, 63, 1700-1710. https://doi.org/10.1016/j.socscimed.2006.04.023

[6] Economic Survey of Pakistan (2015-2016) Ministry of Finance and Economic Affairs Division, Islamabad, Pakistan.

[7] Government of Punjab (2014) Punjab Development Statistics, Lahore, Punjab, Pakistan, 2012-2013.

[8] Abbas, T., Awan, M.S., Aslam, M.A. and Wasqa, M. (2011) Analyzing the Efficiency Differences among Basic Health Units in Sargodha District. Journal of Economics and Behavioral Studies, 3, 42-50.

[9] Li, H., Dong, S. and Liu, T. (2014) Relative Efficiency and Productivity: A Preliminary Exploration of Public Hospitals in Beijing, China. BMC Health Services Research, 14, Article ID: 3329. https://doi.org/10.1186/1472-6963-14-158

[10] Cheng, G. and Zervopoulos P.D. (2014) Estimating the Technical Efficiency of Health Care Systems: A Cross-Country Comparison Using the Directional Distance Function. European Journal of Operational Research, 238, 899-910. https://doi.org/10.1016/j.ejor.2014.05.007

[11] Hernandez, A.R. and Sebastian, M.S. (2014) Assessing the Technical Efficiency of Health Posts in Rural Guatemala: A Data Envelopment Analysis. Global Health Action, 7, 9 p. https://doi.org/10.3402/gha.v7.23190

[12] Rasool, S.A., et al. (2014) Measuring Efficiency of Hospitals by DEA: An Empirical Evidence from Pakistan. International Journal of Public Health Science (IJPHS), 3, 129-136.

[13] Kirigia, J.M. and Asbu, E.Z. (2013) Technical and Scale Efficiency of Public Community Hospitals in Eritrea: An Exploratory Study. Health Economics Review, 3, 1-16. https://doi.org/10.1186/2191-1991-3-6

[14] Sepehrdoust, H. and Rajabi, E. (2012) Regional Human Development Index and Performance of Social Security Hospitals in Iran. African Journal of Business Management, 6, 3076-3081.

[15] Afonso, A., et al. (2005) Non-Parametric Approaches to Education and Health Efficiency in OECD Countries. Journal of Applied Economics, 8, 227-246. https://doi.org/10.1080/15140326.2005.12040626 